\title{
PENGARUH PENGGUNAAN MODEL CONCEPT ATTAINMENT TERHADAP PEMAHAMAN KONSEP MATEMATIKA
}

\author{
Helma Mustika ${ }^{1}$, Endang Sutriana ${ }^{2}$ \\ ${ }^{1}$ Program STudi Pendidikan Matematika STKIP Insan Madani Airmolek \\ ${ }^{2}$ Mahasiswa Program STudi Pendidikan Matematika STKIP Insan Madani Airmolek \\ helmamustika@ymail.com¹, endangsutriana09@gmail.com²
}

\begin{abstract}
The purpose of this research is to know the understanding of mathematical concepts of students with the use of conceptual attainment model is better than the understanding of students' mathematical concepts with conventional learning. This research is quasi experimental research. The research design used was randomized subjects posttest only control group design. By selecting a Class VIII-2 sample as an experimental class and class VIII-1 as a control class of analytical techniques using the t-test as a hypothesis test, the prerequisite test is a normality test and homogeneity test. Based on the hypothesis test, $t$-test, obtained the price $t_{\text {arithmetic }}=3.073$ and price $t_{\text {table }}=-1.997$ at the real level of 0.05 . Because $t_{\text {arithmetic }}>t_{\text {table }}$, so $H_{a}$ accepted and $H_{0}$ rejected. So it can be concluded that the ability to understand the concept of mathematics students using conceptual learning model attainment better than the ability to understand the concept of mathematics students using conventional learning model.
\end{abstract}

\section{Keywords: Concept Attainment, Understanding of Concept}

\begin{abstract}
Abstrak. Tujuan dari penelitian ini adalah untuk mengetahui pemahaman konsep matematika siswa dengan penggunaan model concept attainment lebih baik dari pada pemahaman konsep matematika siswa dengan pembelajaran konvensional. Penelitian ini adalah penelitian quasi eksperimen. Rancangan penelitian yang digunakan adalah randomized subjects posttest only control group design. Dengan memilih sampel Kelas VIII-2 sebagai kelas eksperimen dan kelas VIII-1 sebagai kelas kontrol teknik analisis menggunakan uji-t sebagai uji hipotesis, dengan uji prasyarat adalah uji normalitas dan uji homogenitas. Berdasarkan uji hipotesis, uji-t, diperoleh harga $t_{\text {hitung }}=3,073$ dan harga $t_{\text {tabel }}=-1,997$ pada taraf nyata 0,05 . Karena $t_{\text {hitung }}>t_{\text {tabel }}$, sehingga $\mathrm{H}_{\mathrm{a}}$ diterima dan $\mathrm{H}_{0}$ ditolak. Jadi dapat disimpulkan bahwa kemampuan pemahaman konsep matematika siswa dengan menggunakan model pembelajaran concept attainment lebih baik dari pada kemampuan pemahaman konsep matematika siswa dengan menggunakan model pembelajaran konvensional.
\end{abstract}

Kata Kunci: Concept Attainment, Pemahaman Konsep

\section{PENDAHULUAN}

Matematika merupakan salah satu komponen dari serangkaian mata pelajaran yang mempunyai peranan penting dalam pendidikan. Matematika merupakan salah satu bidang studi yang mendukung perkembangan ilmu pengetahuan dan teknologi. Namun sampai saat ini masih banyak siswa yang merasa matematika sebagai mata pelajaran yang sulit, tidak menyenangkan, bahkan momok yang menakutkan. Hal ini dikarenakan masih banyak siswa yang mengalami kesulitan-kesulitan dalam mengerjakan soal-soal matematika.

Nasution menyebutkan bahwa, "Tanpa konsep, belajar akan sangat terhambat". Akan sangat sulit bagi siswa untuk menuju ke proses pembelajaran yang lebih tinggi jika ia belum memahami konsep. Pemahaman terhadap konsep-konsep matematika merupakan dasar untuk belajar matematika secara bermakna.

Hal ini sejalan dengan tujuan mata pelajaran matematika yang tercantum dalam SI Mata Pelajaran Matematika untuk semua jenjang pendidikan dasar dan menengah dinyatakan bahwa tujuan mata pelajaran matematika disekolah adalah agar siswa mampu: Memahami konsep matematika, menjelaskan keterkaitan antar konsep dan mengaplikasikan konsep atau algoritma, secara luwes, akurat, efisien, dan tepat dalam 
pemecahan masalah, Menggunakan penalaran pada pola dan sifat, melakukan manipulasi matematika dalam membuat generalisasi, menyusun bukti, atau menjelaskan gagasan dan pernyataan matematika, Memecahkan masalah yang meliputi kemampuan memahami masalah,merancang model matematika, menyelesaikan model, dan menafsirkan solusi yang diperoleh, Mengkomunikasikan gagasan dengan simbol, tabel, diagram, atau media lain untuk memperjelas keadaan atau masalah, Memiliki sikap menghargai kegunaan matematika dalam kehidupan, yaitu memiliki rasa ingin tahu, perhatian, dan minat dalam mempelajari matematika, serta sikap ulet dan percaya diri dalam pemecahan masalah, (Wardhani, 2008).

Menurut Duffin dan Simpson (2000) pemahaman adalah kesadaran dari struktur mental yang internal. Pemahaman merupakan suatu hal yang nyata sebagai pengalaman mental seseorang yang potensial atau aktifitas kognitif yang berlangsung pada waktu yang lebih panjang. Winkel (1996) menyatakan pemahaman mencakup kemampuan untuk menangkap makna dan arti dari bahan yang dipelajari. Purwanto (1994:44), "pemahaman adalah tingkat kemampuan yang mengharapkan siswa mampu memahami arti atau konsep, situasi serta fakta yang diketahuinya". Untuk memahami suatu objek secara mendalam, seseorang harus mengetahui: 1) objek itu sendiri; 2) relasinya dengan objek lain yang sejenis; 3) relasinya dengan objek lain yang tidak sejenis; 4) relasidual dengan objek lainnya yang sejenis; 5) relasi dengan objek dalam teori lainnya.

Tennyson (2012) pada kesimpulan bahwa siswa sebenarnya mampu mengembangkan pengetahuan prosedural (bagaimana mencapai konsep) dengan latihan secara intens. Selain itu, ia menyimpulkan bahwa semakin banyak pengetahuan prosedural yang siswa miliki, semakin efektif mereka mencapai dan menerapkan pengetahuan konseptual. Dengan demikian kita memang perlu menerapkan analisis berpikir semacam ini untuk memfasilitasi pembelajaran metakognisi pemerolehan konsep. Informasi disimpan dalam otak ke dalam berbagai tingkatan makna. Semakin bermakna suatu pengalaman maka semakin mudah pengalaman itu dipanggil kembali dan yang kurang bermakna semakin mudah dilupakan. Kilpatrick dan Findell (2001) yaitu menyatakan ulang sebuah konsep yang dipelajari; menggunakan, memanfaatkan, dan memilih prosedur; memberi contoh dan non contoh; mengaplikasikan konsep atau algoritma pemecahan masalah; membandingkan dengan menyajikan contoh dalam berbagai representasi.

Maka berdasarkan hasil observasi yang penulis lakukan di SMP Negeri 3 Lirik ditemukan permasalahan sebagai berikut: masih banyak siswa yang sulit untuk menyelesaikan soal tes pemahaman konsep matematika. Dari hasil tes terlihat bahwa siswa tidak mampu menyelesaikan permasalahan yang diberikan dalam soal sesuai indikator pemahaman konsep, menyatakan ulang sebuah konsep, mengklasifikasi objek menurut tertentu sesuai dengan konsepnya, memberikan contoh dan bukan contoh dari suatu konsep, menyajikan konsep dalam berbagai bentuk representasi matematis, mengembangkan syarat perlu atau syarat cukup dari suatu konsep, menggunakan dan memanfaatkan serta memilih prosedur atau operasi tertentu, mengaplikasikan konsep atau algoritma dalam pemecahan masalah. Hal ini ditunjukkan dari hasil rata-rata tes pemahaman konsep yang diperoleh siswa dibawah kriteria ketuntasan minimum (KKM) yang ditetapkan oleh SMP Negeri 3 Lirik yaitu 76, adapun skor pemahaman konsep matematika yang telah di berikan dapat dilihat pada tabel berikut:

Tabel 1. Hasil Rata-Rata Tes Pemahaman Konsep Siswa Kelas VIII

\begin{tabular}{cccc}
\hline No & Kelas & Banhyak Siswa & $\begin{array}{c}\text { Rata rata Skor tes } \\
\text { Pemahaman Konsep }\end{array}$ \\
\hline 1 & VIII-1 & 33 & 67,45 \\
\hline 2 & VIII-2 & 34 & 68,06 \\
\hline
\end{tabular}


Dari tabel dapat dikatakan bahwa kedua kelas memiliki rata-rata tes pemahaman konsep yang jauh dari KKM, yaitu kelas VIII-1 memperoleh rata-rata 67,45 dan kelas VIII2 memperoleh rata-rata 68,06. Untuk mengatasi hal tersebut maka salah satu alternatif model pembelajaran yang memungkinkan untuk mengembangkan pemahaman konsep siswa adalah model Concept Attainment. Model ini sangat sesuai untuk meningkatkan pemahaman konsep karena model concept attainment sangat menitik beratkan pada proses pencapaian konsep dari materi yang dipelajari.

Model pembelajaran concept attainment menurut Arends (2012) adalah salah satu cara untuk memberikan ide-ide baru dan memperluas serta mengubah skemata yang sudah ada. Pembelajaran concept attainment merupakan proses mencari dan mendaftar sifat-sifat yang dapat digunakan untuk membedakan contoh-contoh yang tidak tepat dari berbagai kategori. Implementasi model concept attainment dapat dijadikan salah satu cara agar siswa dapat menjadi aktif dan termotivasi untuk belajar sehingga tujuan pembelajaran dapat tercapai dengan baik. Hal ini karena siswa dituntut untuk menemukan konsep yang sedang dipelajari melalui pertanyaan-pertanyaan yang diberikan oleh guru.

Model pembelajaran concept attainment menitik beratkan pada pembentukan konsep dan menuntut siswa untuk menemukan konsep tertentu melalui penelaahan masalah, perumusan, dan pengujian hipotesis sehingga siswa yakin dengan konsep yang mereka temukan. Model pembelajaran ini dapat digunakan sebagai alternatif pembelajaran, sebab dalam fase dapat memfasilitasi guru dan siswa untuk menciptakan kegiatan pembelajaran yang mengutamakan perubahan konseptual pada siswa.

Joyce, et al (2011) menyebutkan, model ini memiliki struktur pengajaran yang meliputi (1) penyajian data dan identifikasi konsep, (2) pengujian pencapaian konsep, dan (3) analisis strategi-strategi berpikir. Model ini membantu siswa menemukan pengertian konsep secara lebih matang dengan bimbingan guru. Model ini juga membantu siswa mengklarifikasi ide-ide untuk mencermati aspek dari sebuah konsep. Oleh karena itu, model ini diharapkan akan meningkatkan kemampuan pemahaman konsep siswa khususnya pada materi bangun ruang sisi datar. Maka berdasarkan uraian di atas yang menjadi fokus penelitian ini adalah apakah kemampuan pemahaman konsep siswa dengan menggunakan model concept attainment lebih baik dari pada kemampuan pemahaman konsep siswa dengan menggunakan model konvensional pada kelas VIII SMP Negeri 3 Lirik.

\section{METODE}

Jenis penelitian ini adalah Quasi Experimental Design. Rancangan penelitian yang digunakan adalah Randomized Subject Posttes only control group design dibawah ini:

Tabel 2. Randomized Subject Posttes Only Control Group Design

\begin{tabular}{cccc}
\hline & Grup & Variabel Terikat & Posttes \\
\hline $\mathrm{R}$ & Eksperimen & $\mathrm{X}$ & $\mathrm{Y}_{2}$ \\
\hline $\mathrm{R}$ & Kontrol & - & $\mathrm{Y}_{2}$ \\
\hline
\end{tabular}

Keterangan:

$\mathrm{R}$ : Random

$\mathrm{X}$ : Perlakuan pembelajaran dengan model pembelajaran Concept Attainment

$\mathrm{Y}_{2}$ : Tes kemampuan pemahaman konsep matematika siswa

Dalam desain ini terdapat dua kelompok yang masing-masing dipilih secara random (R). Kelompok pertama diberi perlakuan (X) dan kelompok yang lain tidak. Kelompok yang diberikan perlakuan disebut kelompok eksperimen dan kelompok yang tidak diberikan perlakuan disebut kelompok kontrol. Adapun sampel dalam penelitian ini yaitu kelas VIII-2 sebagai kelas eksperimen dan kelas VIII-1 sebagai kelas kontrol. Instrumen 
penelitian pada penelitian ini berupa tes kemampuan pemahaman konsep matematika siswa yang dilaksanakan di akhir penelitian. Sebelum instrumen digunakan maka terlebih dahulu diuji cobakan pada kelas yang lain guna mengetahui instrumen tersebut layak untuk digunakan. Analisis data dalam penelitian ini menggunakan uji statistic uji-t.

\section{HASIL DAN PEMBAHASAN \\ Hasil}

Dalam penelitian ini, pada kelas eksperimen diberikan perlakuan sebagai variabel bebasnya yaitu penerapan model Concept Attainment sedangkan pada kelas kontrol tidak diberikan perlakuan artinya pelaksanaan pembelajaran seperti biasa (konvensional). Setelah dilaksanakan penelitian data yang diperoleh dianalisis variabel terikatnya, dimana variabel terikatnya adalah kemampuan Pemahaman matematika siswa.

Pengumpulan data mengenai hasil kemampuan pemahaman konsep matematika siswa dengan menggunakan tes pemahaman konsep matematika. Tes diberikan kepada kedua kelas sampel. Soal yang diberikan berbentuk uraian sebanyak 5 butir dengan alokasi waktu 80 menit. Tes pemahaman konsep ini diikuti sebanyak 67 siswa terdiri dari 34 siswa kelas eksperimen dan 33 siswa kelas kontrol. Rata-rata hasil tes kemampuan pemahaman konsep siswa kelas eksperimen dan kelas kontrol dapat dlihat pada Tabel 3 berikut.

Tabel 3. Rata-Rata Hasil Tes Pemahaman Konsep Matematika Siswa

\begin{tabular}{lccccc}
\hline \multicolumn{1}{c}{ Kelas } & $\mathbf{N}$ & $\begin{array}{c}\text { Jumlah skor } \\
\text { siswa }\left(\sum \boldsymbol{x}\right)\end{array}$ & $\begin{array}{c}\text { Rata-rata } \\
\text { skor siswa } \\
(\overline{\boldsymbol{x}})\end{array}$ & $\begin{array}{c}\text { Simpangan } \\
\text { Baku }(\mathbf{S})\end{array}$ & $\begin{array}{c}\text { Variansi } \\
\left(\mathbf{S}^{\mathbf{2}}\right)\end{array}$ \\
\hline Eksperimen & 34 & 2732 & 80,35 & 6,44 & 41,42 \\
\hline Kontrol & 33 & 2482 & 75,21 & 7,28 & 53,09 \\
\hline
\end{tabular}

Dari Tabel 3 terlihat bahwa terdapat perbedaan nilai rata-rata hasil tes pemahaman konsep kelas eksperimen dan kelas kontrol. Rata-rata yang diperoleh kelas eksperimen adalah 80,35, rata-rata pada kelas kontrol adalah 75,21. Menunjukan rata-rata kelas eksperimen lebih tinggi daripada kelas kontrol. Sedangkan simpangan baku kelas eksperimen adalah 6,44, simpangan baku kelas kontrol 7,28. Adapun variansi kelas eksperimen adalah 41,42, variansi kelas kontrol adalah 53,09. daripada kelas kontrol, artinya semakin kecil simpangan baku dan variansi maka data tidak terlalu menyebar dan menunjukan data semakin baik. Dari uraian tersebut dapat disimpulkan bahwa hasil tes kemampuan pemahaman konsep kelas eksperimen lebih baik dari hasil tes kemampuan pemahaman konsep kelas kontrol. Disamping itu perbedaan kemampuan pemahaman konsep antara kelas eksperimen dan kelas kontrol dapat dilihat melalui hasil analisa pada setiap butir soal. Untuk lebih jelasnya perbedaan kemampuan pemahaman konsep matematika siswa antara kelas eksperimen dan kelas kontrol dapat dilihat pada Gambar 1 berikut. 


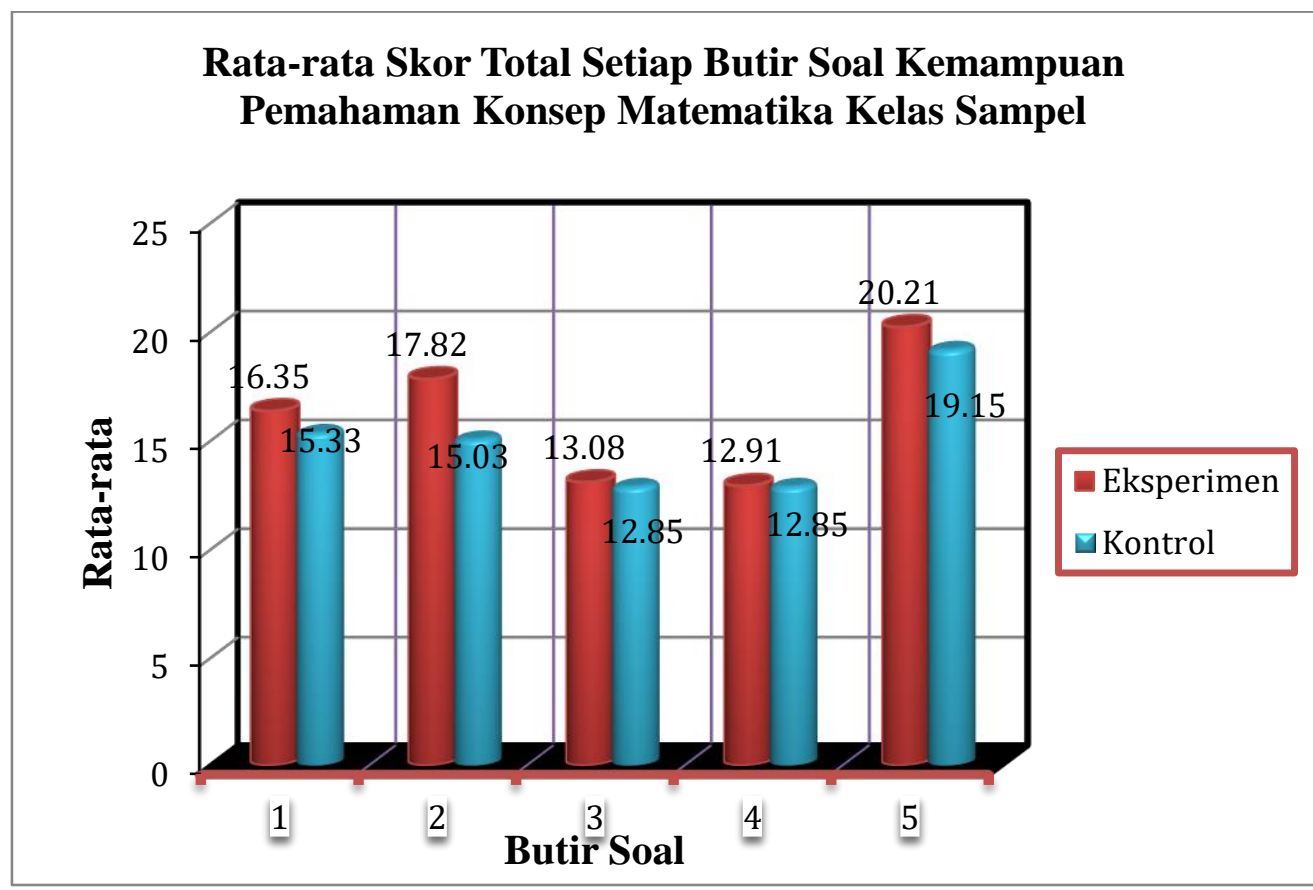

Gambar 1. Rata-Rata Skor Setiap Indikator Kemampuan Pemahaman Konsep Matematika Kelas Sampel Per Butir Soal

Dari Gambar 1 terlihat bahwa pada soal 1 sampai dengan soal 5 kelas eksperimen memiliki frekuensi lebih tinggi dibandingkan dengan kelas kontrol. Pada soal 1 kelas eksperimen memiliki rata-rata 16,35 dan kelas kontrol 15,33. Pada soal 2 kelas eksperimen memiliki rata-rata 17,82 dan kelas kontrol 15,03. Pada soal 3 kelas eksperimen memiliki rata-rata 13,08 dan kelas control 12,85. Pada soal 4 kelas eksperimen memiliki rata-rata 12,91 dan kelas kontrol 12,85. Pada soal 5 kelas eksperimen memiliki rata-rata 20,21 dan kelas kontrol 19,15.

Data yang diperoleh dari hasil tes pemahaman konsep matematika siswa dilakukan analisis data secara statistik. Sebelum melakukan uji hipotesis terlebih dahulu dilakukan uji normalitas dan uji homogenitas variansi dengan menggunakan software SPSS 22.

\section{a. Uji Normalitas}

Uji normalitas dilakukan dengan menggunakan software SPSS 22. Uji ini dilakukan bertujuan untuk melihat apakah sampel berdistribusi normal atau tidak. Uji ini dilakukan kepada kedua kelas sampel yaitu kelas eksperimen dan kelas kontrol. Hasil perhitungan uji normalitas kedua sampel diperoleh nilai Sig. sebesar 0.200. Karena signifikan pada kedua kelas sampel lebih besar dari $\alpha=0,05$ maka dapat disimpulkan bahwa kedua kelas sampel berdistribusi normal.

\section{b. Uji Homogenitas}

Uji homogenitas dianalisis dengan menggunakan software SPSS 22. Uji homogenitas bertujuan untuk melihat apakah kedua sampel mempunyai variansi yang homogen atau tidak. Nilai signifikan yang diperoleh adalah 0,362 dan $\alpha=0,05$. Karena signifikan $\geq \alpha$ maka dapat disimpulkan bahwa kedua kelas sampel memiliki variansi yang homongenitas.

\section{c. Uji Hipotesis}

Setelah sampel berdistribusi normal dan memiliki variansi yang homogen maka dilanjutkan dengan uji hipotesis dengan cara menggunakan Uji-t. Hasil analisis perhitungan uji t dapat dilihat pada tabel berikut. 
Tabel 4. Hasil Perhitungan Uji Hipotesis Kelas Sampel

\begin{tabular}{ccccccc}
\hline $\begin{array}{c}\text { Sampel } \\
\text { Data }\end{array}$ & Nilai $\alpha$ & $\begin{array}{c}\text { Nilai Sign } \\
(2-t a i l e d)\end{array}$ & df & Thitung $_{\text {tabel }}$ & Keputusan \\
\hline Posttest & 0,05 & 0,003 & 65 & 3,073 & $-1,997$ & Terima $\mathrm{H}_{\mathrm{a}}$
\end{tabular}

Berdasarkan tabel 4 diatas terlihat bahwa $t_{\text {hitung }}>\mathrm{t}_{\text {tabel }}$ atau 3,073>-1,997 maka $\mathrm{H}_{0}$ ditolak dan terima $\mathrm{H}_{\mathrm{a}}$. Jadi dapat disimpulkan bahwa "kemampuan pemahaman konsep matematika siswa dengan menggunakan model concept attainment lebih baik dari pada pemahaman konsep siswa dengan model konvensional ".

\section{Pembahasan}

Berdasarkan hasil penelitian yang telah dilakukan ternyata pemahaman konsep matematika siswa yang di ajar dengan menggunakan model concept attainment lebih baik dari pada pemahaman konsep matematika yang diajar dengan menggunakan model konvensional. Hal ini dikarenakan pada pembelajaran dengan menggunakan model concept attainment sangat menekankan pada pencapaian konsep sehingga semua indikator pemahaman konsep dapat tercapai.

Berikut ini disajikan deskripsi dari bentuk-bentuk indikator kemampuan pemahaman konsep matematika siswa pada kelas eksperimen dan kelas kontrol yang diperoleh dari hasil tes pemahaman konsep.

a) Menyatakan ulang suatu konsep

Kemampuan menyatakan ulang suatu konsep pada kelas sampel ditinjau dari hasil posttest siswa pada soal no. 1, 3, 4 dan 5 berikut ini.

\section{Soal no. 1}

Perhatikanlah gambar kubus dibawah ini!

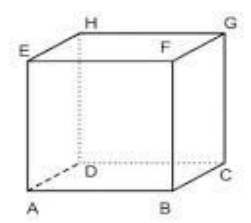

Dari gambar kubus diatas, maka:

a. Jelaskanlah yang kamu ketahui tentang titik sudut, rusuk, diagonal bidang, diagonal ruang, dan bidang diagonal.

b. Tentukanlah titik sudut, rusuk, diagonal bidang, diagonal ruang, dan bidang diagonal pada gambar kubus diatas.

Pada soal di atas, siswa di minta untuk menyebutkan defenisi unsur-unsur kubus , kemudian siswa akan mengetahui unsur-unsur kubus dari gambar yang tertera di soal dengan mengingat kembali konsep unsur-unsur bangun ruang yaitu kubus. Jawaban dari soal no. 1 tersebut pada kelas sampel, diambil dari perwakilan siswa pada kelas eksperimen dan kelas kontrol. Jawaban siswa pada kelas eksperimen dan kelas kontrol dapat dilihat pada Gambar 2 dan 3 dibawah ini. 


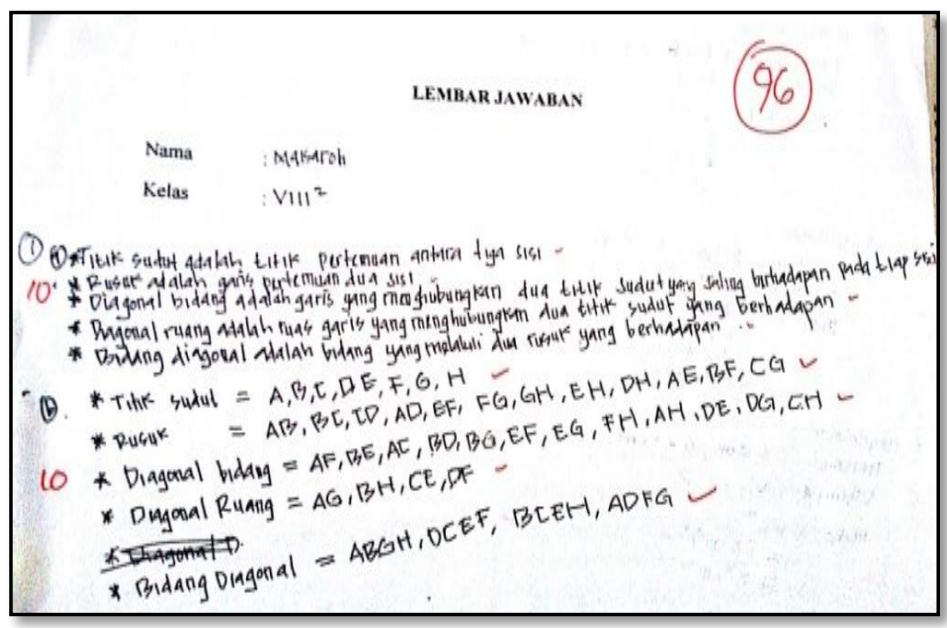

Gambar 2. Jawaban Siswa Kelas Eksperimen

Berdasarkan Gambar 2 diatas, hasil analisis jawaban siswa kelas eksperimen dalam menjawab soal no.1 terlihat bahwa siswa sudah dapat mengingat, memilih serta menyatakan konsep yang relevan dengan informasi, tujuan serta permasalahan yang diperoleh dari soal. Misalnya menentukan unsur-unsur kubus, Kemudian dilanjutkan dengan pengorganisasian informasi secara tepat oleh siswa. Dalam proses pengorganisasian dan pemilihan konsep itu sendiri didasari kemampuan siswa dalam melakukan keterkaitan antar konsep. Disamping itu proses berpikir siswa lebih terarah dan konseptual, sehingga mencapai hasil akhir yang benar. Hal ini terlihat pada jawaban siswa, dimana siswa dapat menjawab soal beserta keterangan memperoleh hasil matematika dengan benar.

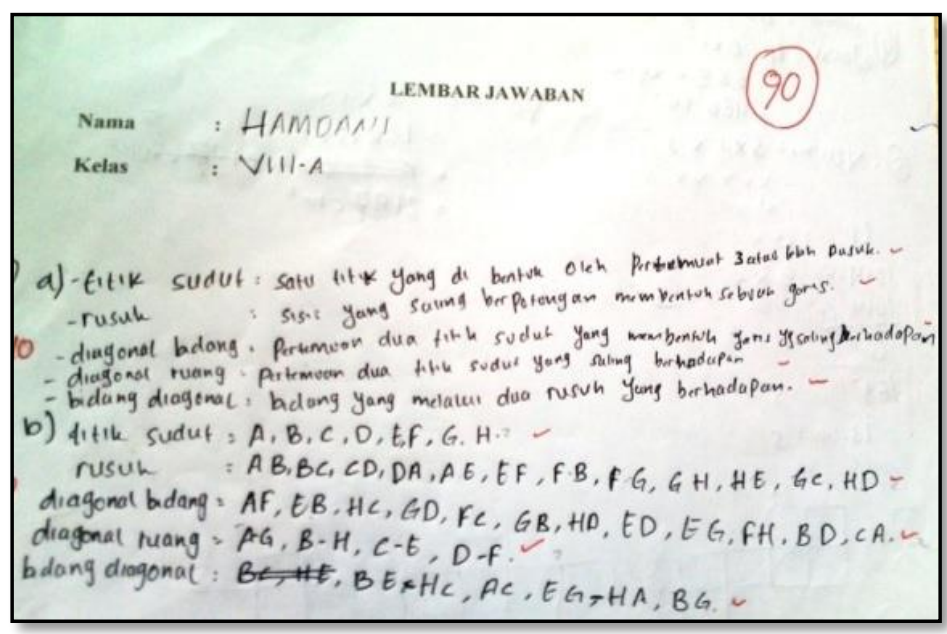

Gambar 3. Jawaban Siswa Kelas Kontrol

Berdasarkan Gambar 3 diatas, hasil analisis jawaban siswa kelas kontrol dalam menjawab soal no. 1 dimana siswa bisa menjawabnya dengan benar, Namun jawaban siswa pada kelas kontrol ini tidak lengkap, ini terlihat pada jawaban siswa yang tidak bisa membedakan mana yang diagonal bidang dan mana yang bidang diagonal. Perbedaan ini dikarenakan siswa kelas kontrol belum dapat menyatakan konsep dengan lebih lengkap dan jelas. Dari deskripsi jawaban siswa kelas eksperimen dan kontrol, terlihat bahwa kemampuan menyatakan ulang suatu konsep matematika pada kelas eksperimen lebih baik dari pada kelas kontrol. Hal ini dikarenakan pada kelas eksperimen pembelajarannya menggunakan model Concept attainment dimana pada proses pembelajaran siswa dituntut untuk berpikir secara mandiri maupun kelompok, sehingga siswa berperan aktif dan rileks, akibatnya siswa mudah untuk memahami suatu konsep. 


\section{Soal no. 3}

Sebuah kubus rusuknya adalah $2 \mathrm{a}$, tentukan rumus luas permukaan kubus tersebut.

Pada soal no.3 siswa diminta untuk menentukan rumus luas permukaan kubus jika panjang rusuknya diketahui. Jawaban dari soal no. 3 tersebut pada kelas sampel, diambil dari perwakilan siswa pada kelas eksperimen dan kelas kontrol. Jawaban siswa pada kelas eksperimen dan kelas kontrol dapat dilihat pada gambar 4 dan 5 dibawah ini.

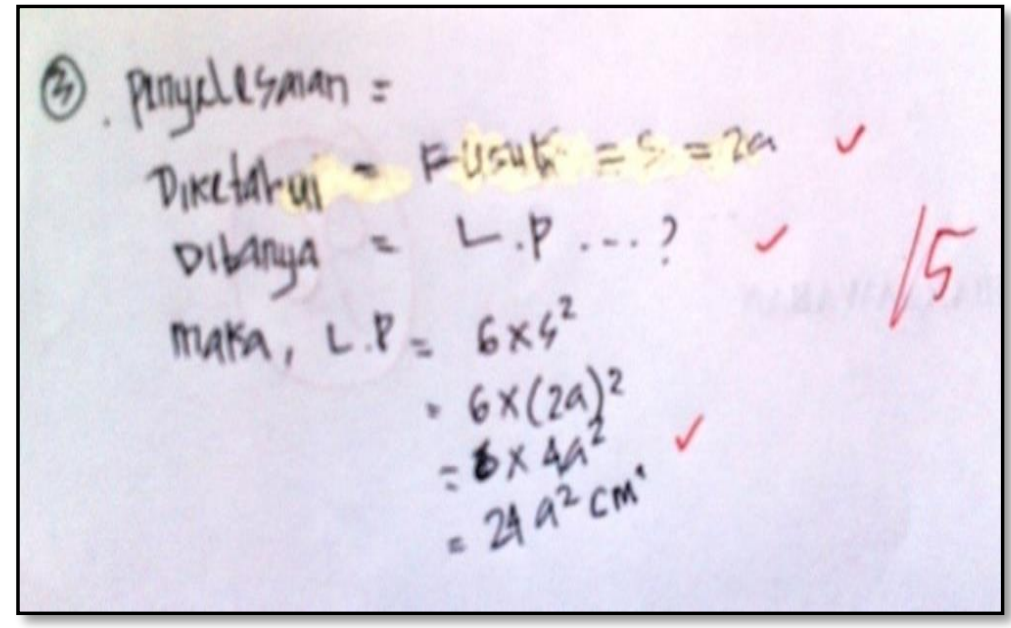

Gambar 4. Jawaban Siswa Kelas Eksperimen

Berdasarkan gambar 4 diatas, hasil analisis jawaban siswa kelas eksperimen dalam menjawab soal no. 3 terlihat bahwa siswa sudah dapat mengingat, memahami serta menyatakan ulang suatu konsep dan dapat melihat permasalahn dari soal, hal ini dapat dilihat dari proses siswa menjawab soal dengan langkah-langkah yang runtun dan benar. Misalnya siswa diminta menemukan rumus luas permukaan kubus, siswa mampu memahami apa yang diketahui dan ditanya dari soal tersebut.

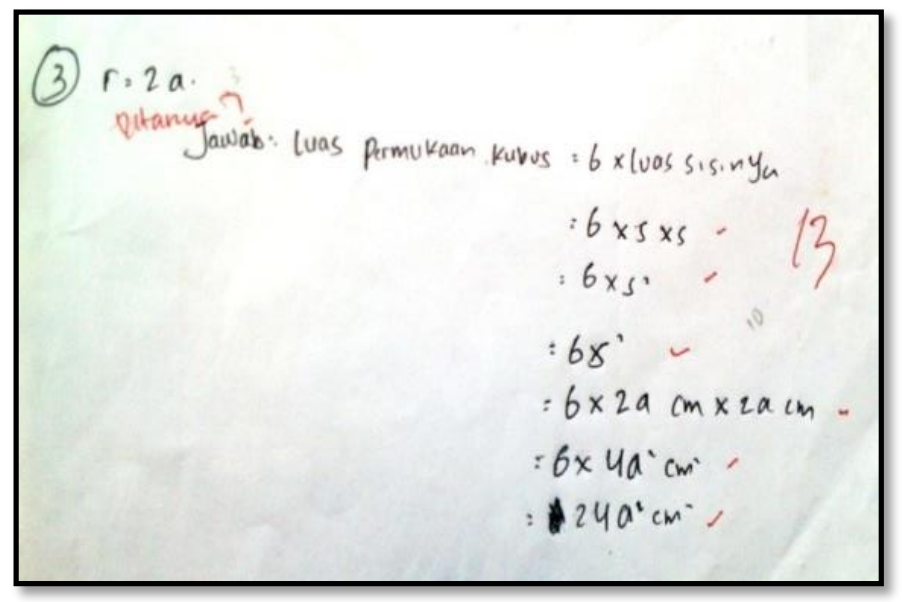

Gambar 5. Jawaban Siswa Kelas Kontrol

Berdasarkan gambar 5 diatas, hasil analisis jawaban siswa kelas kontrol dalam menjawab soal no. 3 dimana siswa mampu menjawab dengan benar, namun tidak membuat langkah-langkah penyelesaiannya secara runtun, juga terlihat pada penulisan rumus yang berulang-ulang. Hal ini karena siswa belum sepenuhnya memahami konsep, sehingga siswa tidak dapat menentukan langkah-langkah penyelesaian dengan benar.

\section{b) Mengklasifikasi objek menurut sifat tertentu sesuai dengan konsepnya}

Mengklasifikasi objek menurut sifat tertentu sesuai dengan konsepnya dapat ditinjau dari hasil tes siswa kelas sampel pada no. 1 diatas (mencakup indikator a), dimana siswa pada kelas eksperimen (gambar 2) mampu mengklasifikasi informasi yang diperoleh menurut konsep yang relevan dengan informasi, sehingga jawaban akhir siswa tersebut 
jelas dan benar. Sedangkan jawaban siswa kelas kontrol (gambar 3) pada soal no. 1 benar namun tidak lengkap.

\section{c) Memberikan contoh dan bukan contoh dari suatu konsep}

Memberikan contoh dan bukan contoh dari suatu konsep dapat ditinjau dari hasil tes siswa kelas sampel pada no. 2 berikut ini.

\section{Soal no. 2}

Yani membeli cincin untuk ibunya sebagai hadiah ulang tahun. Kotak cincin tersebut berbentuk kubus. Agar hadiah tersebut terlihat cantik, maka yani membungkusnya dengan menggunakan kertas kado. Gambarkanlah garis yang terbentuk dari lipatan kertas kado tersebut (minimal 5).

Pada soal no. 2 siswa diminta untuk membaca dan menemukan permasalahn dalam soal tersebut, kemudian menentukan penyelesaiannya (membuat jaring-jaring kubus). Jawaban dari soal no. 2 tersebut pada kelas sampel, diambil dari perwakilan siswa pada kelas eksperimen dan kelas kontrol. Jawaban siswa pada kelas eksperimen dan kelas kontrol dapat dilihat pada gambar 6 dan 7 dibawah ini.

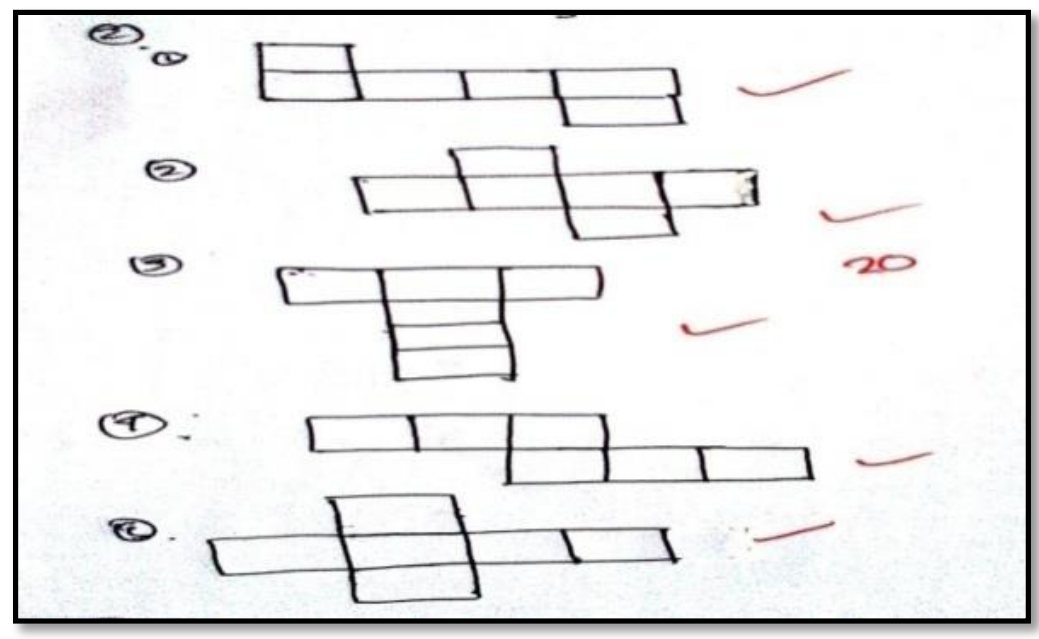

Gambar 6. Jawaban Siswa Kelas Eksperimen

Berdasarkan gambar 6 diatas, hasil analisis jawaban siswa pada kelas eksperimen terlihat bahwa siswa sudah memahami sepenuhnya permasalahan yang ada didalam soal, kemudian siswa mampu membuat penyelesaian dengan benar, artinya siswa mampu membedakan mana yang merupakan jaring-jaring kubus dan mana yang bukan merupakan jaring-jaring kubus.

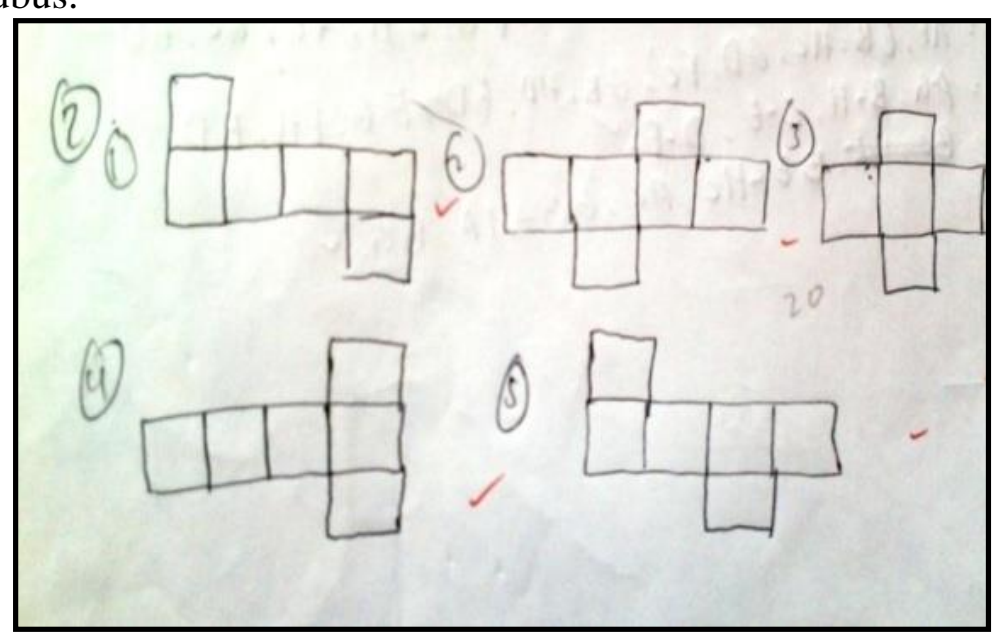

Gambar 7. Jawaban Siswa Kelas Kontrol 
Berdasarkan gambar 7 diatas, hasil analisis jawaban siswa pada kelas kontrol terlihat bahwa siswa sudah memahami permasalahan yang ada didalam soal, kemudian siswa mampu membuat penyelesaian, namun dalam penyelesaiannya masih ada jawaban yang salah, artinya siswa belum mampu membedakan mana yang merupakan jaring-jaring kubus dan mana yang bukan merupakan jaring-jaring kubus.

\section{d) Menyajikan konsep dalam berbagai bentuk representasi matematis}

Menyajikan konsep dalam berbagai bentuk representasi matematis dapat ditinjau dari hasil tes siswa kelas sampel pada no. 2 dan 5 seperti yang terdapat pada indikator $c$ dan indikator $a$. Dimana siswa dalam menyajikan konsep harus terlebih dahulu membaca dan memahami sepenuhnya keterkaitan antar konsep. Adapun jawaban siswa pada kelas eksperimen sudah mampu menyajikan konsep dalam berbagai bentuk representasi matematis dimana siswa sudah mampu menyimpulkan jawaban yang diperolehnya sehingga jawaban terstruktur, jelas dan benar. Sedangkan jawaban siswa pada kelas kontrol terlihat bahwa siswa mampu menyajikan jawaban dalam berbagai bentuk representasi matematis, namun terlihat kurang percaya diri dalam menjawab sehingga jawaban yang diperoleh siswa terjadi kekeliruan.

\section{e) Mengembangkan syarat perlu atau syarat cukup dari suatu konsep}

Mengembangkan syarat perlu atau syarat cukup dari suatu konsep dapat ditinjau dari hasil tes siswa kelas sampel pada no. 5 (terdapat pada indikator a dan indikator d).

\section{Soal no. 5}

Tuliskan rumus volume kubus dengan panjang rusuk $\mathrm{x} \mathrm{cm}$. Kemudian hitunglah volume kubus tersebut jika diketahui luas permukaannya $1014 \mathrm{~cm}^{2}$.

Pada soal no. 5 siswa diminta untuk menemukan rumus volume kubus, kemudian menghitung volume kubus tersebut jika luas permukaan kubus diketahui. Jawaban dari soal no.5 tersebut pada kelas sampel, diambil dari perwakilan siswa pada kelas eksperimen dan kelas kontrol. Jawaban siswa pada kelas eksperimen dan kelas kontrol dapat dilihat pada gambar 8 dan 9 dibawah ini.

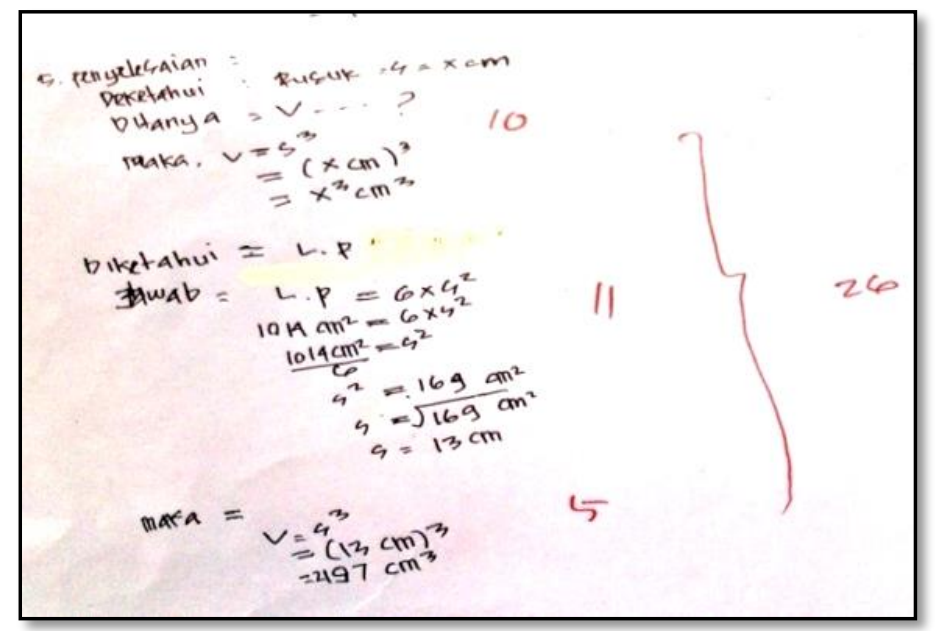

Gambar 8. Jawaban Siswa Kelas Eksperimen

Berdasarkan gambar 8 diatas, hasil analisis jawaban siswa kelas eksperimen dalam menjawab soal no. 5 (hampir sama dengan soal no.3 dan 4) terlihat bahwa siswa sudah dapat mengingat, memahami serta menyatakan ulang suatu konsep dan dapat melihat permasalahn dari soal, hal ini dapat dilihat dari proses siswa menjawab soal dengan langkah-langkah yang runtun. Misalnya siswa diminta menemukan rumus volume kubus dan menghitung volume kubus jika luas permukaan kubus tersebut diketahui, siswa mampu memahami apa yang diketahui dan ditanya dari soal tersebut. Sehingga skor yang diperoleh siswa kelas eksperimen lebih tinggi daripada skor yang diperoleh siswa kelas kontrol. 


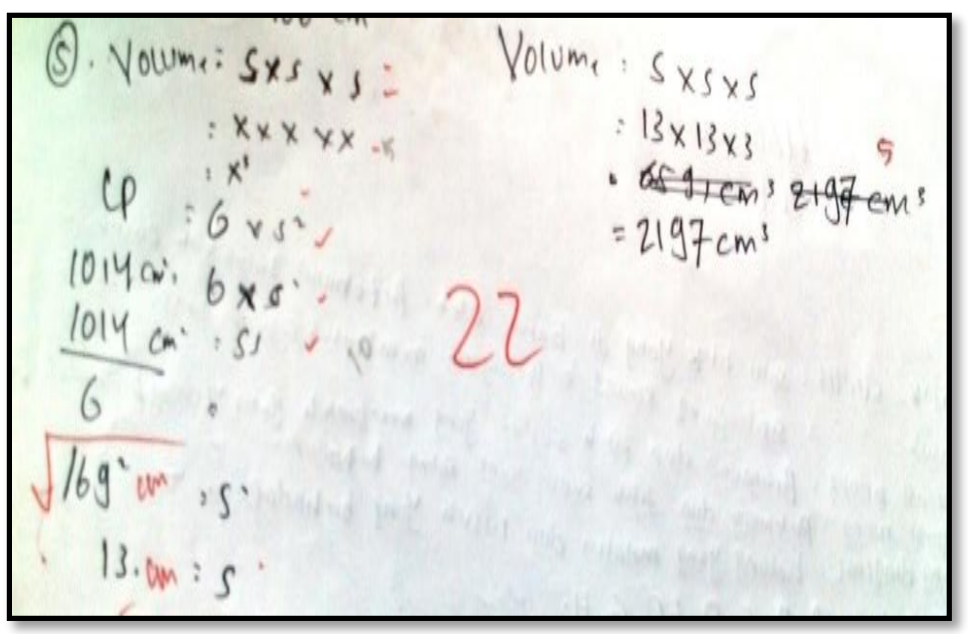

Gambar 9. Jawaban Siswa Kelas Eksperimen

Berdasarkan gambar 9 diatas, hasil analisis jawaban siswa kelas kontrol dalam menjawab soal no. 5 terlihat bahwa siswa juga menjawab dengan tepat, tetapi dalam penyelesaiannya siswa belum mampu memahami setiap langkah-langkah yang dilaluinya. Pada soal tersebut selain memenuhi indikator a dan $d$, siswa juga diminta untuk mengembangkan syarat perlu atau syarat cukup dari suatu konsep volume kubus agar tidak terjadi kekeliruan dalam menyelesaikan permasalahan pada soal tersebut. Adapun jawaban siswa pada kelas eksperimen dan kelas kontrol juga telah dijabarkan pada indikatorindikator sebelumnya dimana jawaban siswa kelas eksperimen lebih baik daripada jawaban siswa kelas kontrol.

\section{f) Menggunakan dan memanfaatkan serta memilih prosedur atau operasi tertentu}

Menggunakan dan memanfaatkan serta memilih prosedur atau operasi tertentu dapat ditinjau dari soal tes pada no. 3, 4 dan 5 .

\section{Soal no. 4}

Hitunglah luas permukaan kubus jika diketahui panjang rusuknya $9 \mathrm{~cm}$.

Pada soal no. 4 siswa diminta untuk menghitung luas permukaan kubus jika panjang rusuknya diketahui. Jawaban dari soal no. 4 tersebut pada kelas sampel, diambil dari perwakilan siswa pada kelas eksperimen dan kelas kontrol. Jawaban siswa pada kelas eksperimen dan kelas kontrol dapat dilihat pada gambar 10 dan 11 dibawah ini.

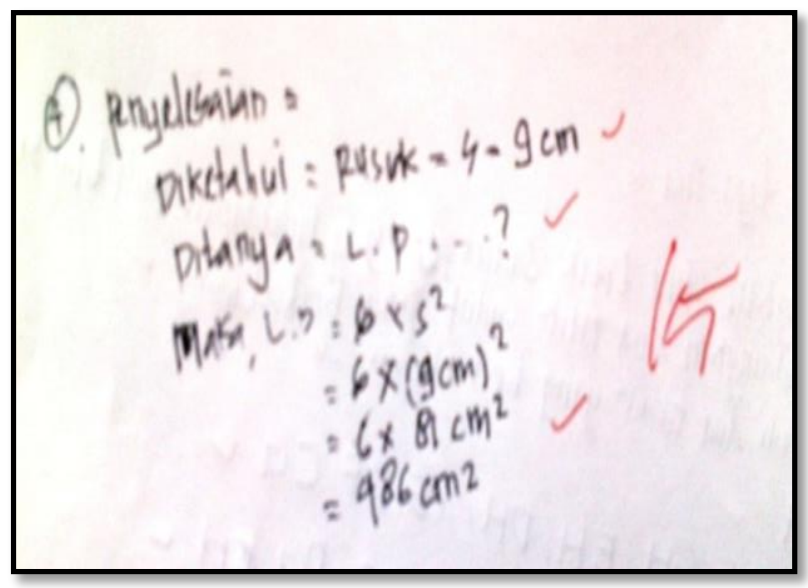

Gambar 10. Jawaban Siswa Kelas Eksperimen

Berdasarkan gambar 10 diatas, hasil analisis jawaban siswa kelas eksperimen dalam menjawab soal no. 4 terlihat bahwa siswa sudah dapat mengingat, memahami serta menyatakan ulang suatu konsep dan dapat melihat permasalahan dari soal, hal ini dapat 
dilihat dari proses siswa menjawab soal dengan langkah-langkah yang runtun dan benar. Misalnya siswa diminta menghitung luas permukaan kubus, siswa mampu memahami apa yang diketahui dan ditanya dari soal tersebut.

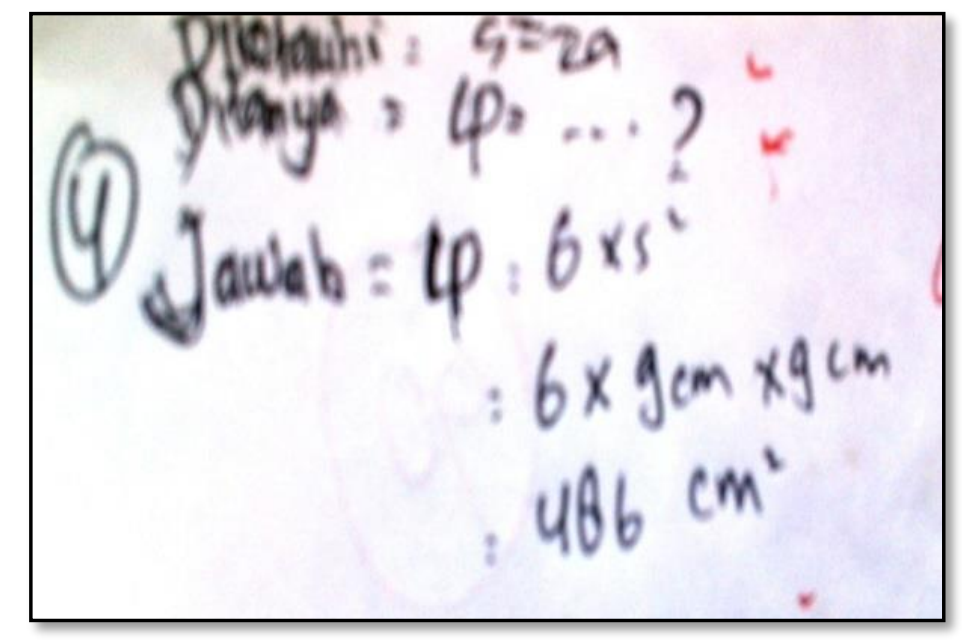

Gambar 11. Jawaban Siswa Kelas Kontrol

Berdasarkan gambar 11 diatas, hasil analisis jawaban siswa kelas kontrol dalam menjawab soal no. 4 dimana siswa mampu memperoleh hasil dengan benar, namun dari langkah-langkah pengerjaannya siswa belum mampu melihat apa yang diketahui dalam soal, hal ini dapat dilihat dari apa yang diketahui dan apa yang di tulis pada jawabannya.

Indikator ini paling banyak keterkaitannya pada soal tes karena dalam penyelesaian permasalahan pada soal matematika memerlukan prosedur dan operasi perhitungan yang tepat dan benar. Untuk soal no. 3 dan 5 tidak dijabarkan lagi dikarenakan soal pada nomor tersebut juga terkait dengan indikator lain yaitu pada indikator $a, d$ dan $e$, dimana pada masing-masing jawaban siswa kelas sampel dapat dilihat perbedaannya di tiap indikator $a$, $d$ dan $e$ di atas. Jawaban siswa kelas eksperimen lebih baik dari kelas kontrol karena cara siswa menjawab soal lebih terstruktur mengikuti prosedur yang tepat untuk digunakan dalam memecahkan masalah.

\section{g) Mengaplikasikan konsep atau algoritma dalam pemecahan masalah}

Mengaplikasikan konsep atau algoritma dalam pemecahan masalah dapat ditinjau pada soal tes no. 2 (terdapat juga pada indikator $\mathrm{c}$ dan d), dimana siswa diberikan soal berupa permasalahan sehari-hari kemudian siswa diminta untuk membaca dan memahami, kemudian menyimpulkan langkah-langkah yang tepat untuk menyelesaikan permasalahan tersebut dengan mengaplikasikan konsep-konsep yang sudah dipelajari sebelumnya.

Dari jawaban-jawaban antara kelas eksperimen dan kelas kontrol maka dapat disimpulkan bahwa kemampuan pemahaman konsep matematika kelas eksperimen lebih baik dari pada kemampuan pemahaman konsep pada kelas kontrol. Hal ini juga dapat melatih siswa agar siswa tidak hanya terfokus pada apa yang diberikan oleh guru, namun siswa juga dapat mengetahui pembelajaran melalui komunikasi secara kelompok. Ini sesuai dengan langkah-langkah model pembelajaran concept attainment yaitu siswa dalam masing-masing kelompok menilai dengan memberikan pandangan dan pemikirannya mengenai tugas yang sedang mereka kerjakan.

Perbedaan jawaban antara kelas eksperimen dan kelas kontrol juga diperkuat dengan hasil rata-rata antar kedua kelas tersebut. Dari deskripsi dan analisis data tes akhir terlihat bahwa hasil belajar matematika siswa kelas eksperimen lebih baik daripada kelas kontrol. Hal ini dapat dilihat dari skor tertinggi, skor terendah dan nilai rata-rata kelas eksperimen yang lebih tinggi dari kelas kontrol. Skor tertinggi kelas eksperimen adalah 96, skor terendah adalah 70, dan nilai rata-rata 80,35. Sedangkan pada kelas kontrol skor tertinggi 
yang diperoleh adalah 90, skor terendah adalah 65, dan dengan nilai rata-rata 75,21. Dengan demikian kemampuan Pemahaman Konsep kelas eksperimen lebih tinggi dari pada kelas kontrol.

\section{KESIMPULAN DAN SARAN}

Berdasarkan hasil penelitian yang telah dilaksanakan dapat disimpulkan bahwa kemampuan pemahaman konsep matematika siswa dengan penerapan model concept attainment lebih baik dari pada pemahaman konsep matematika siswa dengan penerapan model konvensional. Adapun saran dalam penelitian ini adalah dalam penggunaan model concept attainment sebaiknya memperhatikan kesiapan siswa dan kita sebagai guru, serta memperhatikan manajemen waktu pelaksanaan.

\section{DAFTAR RUJUKAN}

Arends, R.I. 2012. Learning to Teach: 9th Edition. New York: McGraw-Hill Companies, Inc.

Duffin, J. M., Simpson, A. P. 2000. A Search for Understanding. Journal of Mathematical Behavior. 18(4), 415-427.

Joyce, B., Weil, M., \& Calhoun, E. 2011. Model-Model Pengajaran (terjemahan dari Models of Teaching Eighth Edition). Yogyakarta: Pustaka Pelajar.

Kilpatrick, S., Findell, (2001). Adding It Up: Helping Children Learn Mathematics. National Academy Press

Purwanto, M. Ngalim. 1994. Prinsip-Prinsip dan Teknik Evaluasi Pengajaran. Bandung: Rosdakarya

Tennyson, R.D. 1992. An educational learning theory for instructional design. Educational Technology, 32(1), 36-41.

Wardhani, S. 2008. Analisis SI dan SKL Mata Pelajaran Matematika SMP/MTs untuk Optimalisasi Tujuan Mata Pelajaran Matematika. Jogjakarta: PPPPTK Matematika, 2008.

Winkel, W. S. 1996. Psikologi Pengajaran. Jakarta: Gramedia. 